\title{
Recombinant Diploid Saccharomyces cerevisiae Strain Development for Rapid Glucose and Xylose Co-Fermentation
}

\author{
Tingting Liu, Shuangcheng Huang and Anli Geng * \\ School of Life Sciences and Chemical Technology, Ngee Ann Polytechnic, Singapore 599489, Singapore; \\ lttf7@sina.com (T.L.); higle945@yahoo.com (S.H.) \\ * Correspondence: gan2@np.edu.sg; Tel.: +65-6460-8617
}

Received: 25 June 2018; Accepted: 25 July 2018; Published: 30 July 2018

\begin{abstract}
Cost-effective production of cellulosic ethanol requires robust microorganisms for rapid co-fermentation of glucose and xylose. This study aims to develop a recombinant diploid xylose-fermenting Saccharomyces cerevisiae strain for efficient conversion of lignocellulosic biomass sugars to ethanol. Episomal plasmids harboring codon-optimized Piromyces sp. E2 xylose isomerase (PirXylA) and Orpinomyces sp. ukk1 xylose (OrpXylA) genes were constructed and transformed into S. cerevisiae. The strain harboring plasmids with tandem PirXylA was favorable for xylose utilization when xylose was used as the sole carbon source, while the strain harboring plasmids with tandem OrpXylA was beneficial for glucose and xylose cofermentation. PirXylA and OrpXylA genes were also individually integrated into the genome of yeast strains in multiple copies. Such integration was beneficial for xylose alcoholic fermentation. The respiration-deficient strain carrying episomal or integrated OrpXylA genes exhibited the best performance for glucose and xylose co-fermentation. This was partly attributed to the high expression levels and activities of xylose isomerase. Mating a respiration-efficient strain carrying the integrated PirXylA gene with a respiration-deficient strain harboring integrated OrpXylA generated a diploid recombinant xylose-fermenting yeast strain STXQ with enhanced cell growth and xylose fermentation. Co-fermentation of $162 \mathrm{~g} \mathrm{~L}^{-1}$ glucose and $95 \mathrm{~g} \mathrm{~L}^{-1}$ xylose generated $120.6 \mathrm{~g} \mathrm{~L}^{-1}$ ethanol in $23 \mathrm{~h}$, with sugar conversion higher than $99 \%$, ethanol yield of $0.47 \mathrm{~g} \mathrm{~g}^{-1}$, and ethanol productivity of $5.26 \mathrm{~g} \mathrm{~L}^{-1} \cdot \mathrm{h}^{-1}$.
\end{abstract}

Keywords: Saccharomyces cerevisiae; diploid; xylose isomerase; xylose fermentation; glucose and xylose co-fermentation; biomass hydrolysate; cellulosic ethanol

\section{Introduction}

Ethanol can be produced from renewable resources such as crops or agricultural waste. It is therefore a sustainable and clean fuel. Further growth in bioethanol production largely depends on the effective conversion of lignocellulosic feedstock such as agricultural and forestry wastes to bioethanol because they are the most abundant polymers of fermentable sugars [1-3].

Saccharomyces cerevisiae is the most effective microorganism for fermenting sugars to ethanol due to its rapid sugar consumption rate, high sugar and ethanol tolerance, and resistance to biomass-derived inhibitors $[4,5]$. Much research has been done to genetically engineer $S$. cerevisiae strains for xylose fermentation [6-10].

Two xylose-assimilating pathways were heterologously engineered in $S$. cerevisiae for xylose-fermenting yeast construction. One focused on the D-xylose isomerase (XI) pathway [11,12], the other focused on the D-xylose reductase (XR) and xylitol dehydrogenase (XDH) pathway [10,13-15]. In the XI pathway, xylose is first isomerized into xylulose by XI and xylulose was then phosphorylated 
into xylulose 5-phosphate by xylulokinase. Xylulose is subsequently metabolized to ethanol through glycolysis in the pentose phosphate pathway [11]. As no xylitol is produced in this pathway, much research focused on the XI pathway construction in xylose-fermenting yeast [12].

However, for all the engineered strains developed, rapid glucose and xylose co-fermentation is still challenging, in particular when sugar concentration is high [4,8-10]. Because fermentation time on mixed-substrate hydrolysates is still not cost-effective, strategies in evolutionary engineering were used to improve fermentation kinetics [16-18] and much research focused on the search for new or engineered sugar transporters [19-21]. More recently, robust diploid S. cerevisiae strains were developed for rapid xylose-fermentation [22-25].

This study aims to develop a recombinant $S$. cerevisiae strain for rapid glucose and xylose co-fermentation through metabolic engineering, evolutionary engineering and strain mating. Firstly, four episomal plasmids containing the two-copy codon-optimized Piromyces sp. E2 XI gene (PirXylA, GenBank accession number AJ249909.1), one-copy codon-optimized Orpinomyces sp. ukk1 XI gene (OrpXylA, GenBank accession number EU411046), one-copy PirXylA and OrpXylA in tandem,

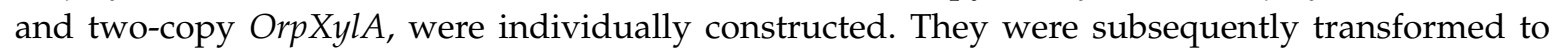
an evolved respiration-deficient yeast strain. Four engineered strains with episomal XI genes were generated and optimal XI functional expression was identified. Afterwards, PirXylA and OrpXylA were separately integrated into the genome of two evolved $S$. cerevisiae strains (one respiration-efficient and the other respiration-deficient) in multiple copies according the methods described previously [26,27]. Four engineered yeasts with integrated XI genes were generated and screened for xylose fermentation or glucose/xylose co-fermentation. In the end, a diploid recombinant xylose-fermenting S. cerevisiae was constructed by mating a respiration-efficient haploid strain with a respiration-deficient haploid strain. To the best of our knowledge, this is the first report on diploid xylose-fermenting yeast strain construction by such strain mating. The resulted diploid yeast strain displayed superior glucose and xylose co-fermentation performance, which far exceeded that by engineered $S$. cerevisiae reported to-date $[28,29]$.

\section{Materials and Methods}

\subsection{Plasmid Construction}

All plasmids used in this work are listed in Table 1. All primers used in this study are listed in Table S1.

E. coli strain DH5 $\alpha$ (Life Technologies, Rockville, MD, USA) were used as the transformation host for plasmid construction. E. coli were grown in LB medium containing $100 \mu \mathrm{g} / \mathrm{mL}$ ampicillin at $30{ }^{\circ} \mathrm{C}$ or $37{ }^{\circ} \mathrm{C}$ for plasmid maintenance [25]. The PGK1 promoter was amplified from genomic DNA of $S$. cerevisiae strain ATCC 24860 and was ligated to pYES2 (Thermo-Fischer Scientific, Singapore) to replace the GAL1 promoter, resulting in pPY1. PirXylA and OrpXylA were synthesized by Integrated DNA Technologies Singapore). Cassettes PGK1p-OrpXylA-CYC1t, PGK1p-PirXylA-CYC1t-PGK1p-OrpXylA-CYC1t, PGK1p-OrpXylA-CYC1t-PGK1p-OrpXylA-CYC1t and PGK1p-PirXylA-CYC1t-PGK1p-PirXylA-CYC1t were cloned into pPY1 individually, resulting in plasmids pPYXo, pPYXpXo, pPYXoXo and pPYXpXp (Figure 1A-D).

NTS2-2 partial fragment ( $\mathrm{pNTS}$ ) was obtained by overlap extension polymerase chain reaction (OE-PCR) of S. cerevisiae ATCC 24860 genomic DNA over 274 bp upstream and 245 bp downstream homologous regions of NTS2-2. The XXUN plasmid (Figure 1E) is an integrating yeast plasmid based on $\mathrm{pPYXpXp}$ whereby the $2 \mu$ origin was replaced with $\mathrm{pNTS}$. The loxP-KanMX4-loxP cassette was amplified from the plasmid pUG6 [30]. Cassettes PGK1p-OrpXylA-CYC1t and loxP-KanMX4-loxP-pNTS were obtained by OE-PCR and then subsequently constructed into plasmid pUC19 [12], resulting in plasmid XoNK (Figure 1F). Both plasmids were digested with SwaI for XI genome integration using NTS2-2 homologous recombinant arms. 
A

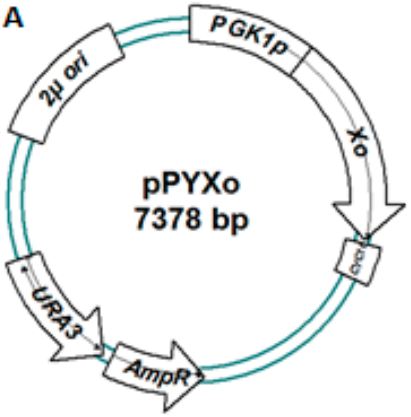

C
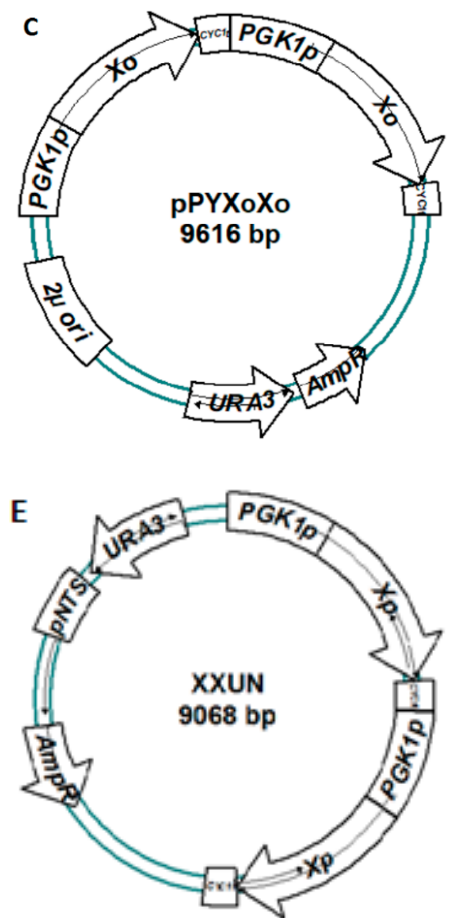

B

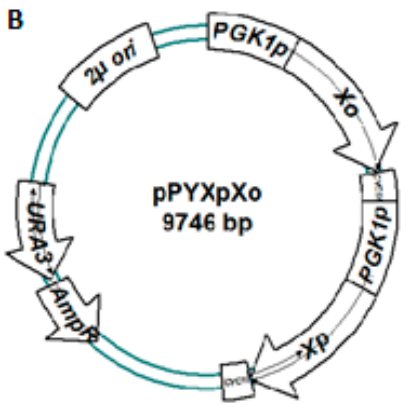

D
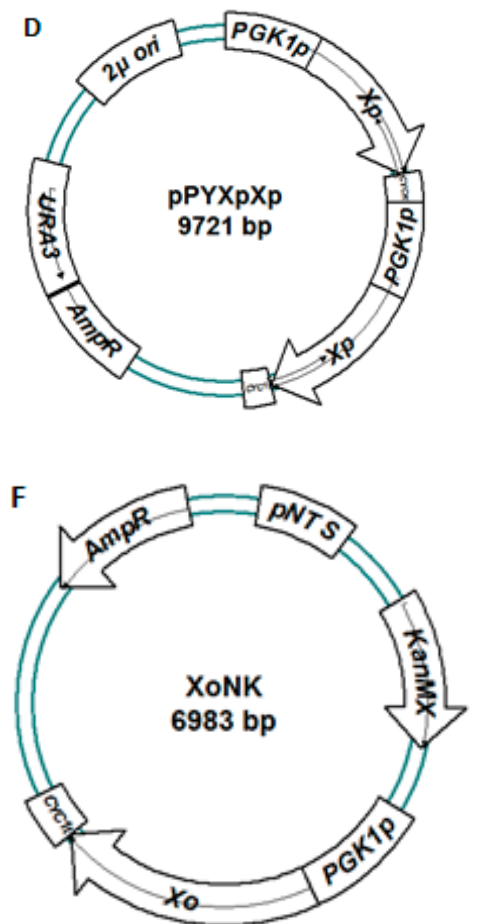

Figure 1. Map of plasmids. (A) pPYXo; (B) pPYXpXo; (C) pPYXoXo; (D) pPYXpXp; (E) XXUN; and $(\mathbf{F})$ XoNK.

\subsection{Strain Construction and Adaptive Evolution}

All strains used in this work are listed in Table 1. S. cerevisiae haploid strains JUK36 $\alpha$ and JUK39a were isolated from the diploid strain S. cerevisiae ATCC 24860. They were both overexpressed with the non-oxidative pentose phosphate pathway (PPP) genes and xylulokinase gene, XKS1. URA3 and GRE3 genes were disrupted in both haploid strains. In addition, the CYC3 gene, encoding cytochrome c heme lyase, was knocked out in strain JUK39a to eliminate respiration [12].

Plasmid pPYXpXp was transformed into strain JUK39a using the LiAc/SS carrier DNA/PEG method [31], resulting in recombinant S. cerevisiae 39aXpXp. The respiration-deficient strain 39aXpXp was evolved by continuous transfer and cultivation in a synthetic medium (SM) containing $6.7 \mathrm{~g} \mathrm{~L}^{-1}$ yeast nitrogen base without amino acids (YNB) (Difco Laboratories Inc., Detroit, MI, USA) and $20 \mathrm{~g} \mathrm{~L}^{-1}$ xylose (SMX) under oxygen-limited conditions according to the protocols described in our earlier report [12]. After 75-day continuous transfer, cell doubling time was reduced from $15.9 \mathrm{~h}$ to $6.4 \mathrm{~h}$. Samples were taken on day 75 and streaked on SMX plates containing $20 \mathrm{~g} \mathrm{~L}^{-1}$ xylose and $20 \mathrm{~g} \mathrm{~L}^{-1}$ agar. Fifteen large single colonies were selected. They were then incubated in $50 \mathrm{~mL}$ SMX medium in $100 \mathrm{~mL}$ Erlenmeyer flasks capped with rubber stoppers, shaken at $200 \mathrm{rpm}$ and $30^{\circ} \mathrm{C}$. Weight loss of the cultures from the 15 colonies was individually measured on Day 4 . The best ethanol-producing strain 
was indicated by the highest weight loss [18]. This strain was denoted 39aXpXp2415, and plasmid pPYXpXp in this strain was removed by streaking the culture on 5-FOA plates [12]. This generated the background strain 39a 2 (Table 1). On the other hand, strain JUK51a_2 (Table 1) was evolved anaerobically in a chemostat with an increase in the dilution rate from 0.01 to $0.14 \mathrm{~h}^{-1}$ on xylose using the method described in our earlier report [12]. The fastest growing strain was selected, and the plasmid pJFX11 was removed according to the above-described method on 5-FOA plates. The background strain $36 \alpha_{2}$ was later obtained (Table 1 ).

Table 1. Strains and plasmids used in this study.

\begin{tabular}{|c|c|c|}
\hline Strains/Plasmid & Genotype/Phenotype & References \\
\hline \multicolumn{3}{|l|}{ Saccharomyces cerevisiae strains } \\
\hline Saccharomyces cerevisiae ATCC 24860 & Obtained from American Type Culture Collection (ATCC) & \\
\hline JUK36 $\alpha$ & $\begin{array}{l}\text { S. cerevisiae ATCC } 24860 \text { segregant; MAT; ura3::loxP; } \\
\text { TKL1::RKIt-RKI1-ADH1p-RPE1t-RPE1-TPI1p-loxP-XKS1t-XKS1-PGK1p- } \\
\text { PDC1p-TAL1-TAL1t-FBA1p; gre3::loxP }\end{array}$ & [12] \\
\hline JUK39a & $\begin{array}{l}\text { S. cerevisiae ATCC } 24860 \text { segregant; } M A T a ; \text { ura3::loxP; } \\
\text { TKL1::RKIt-RKI1-ADH1p-RPE1t-RPE1-TPI1p-loxP-XKS1t-XKS1-PGK1p- } \\
\text { PDC1p-TAL1-TAL1t-FBA1p; gre3::loxP; cyc3::loxP }\end{array}$ & [12] \\
\hline JUK51a_2 & JUK36 $\alpha$ derivative; $\{$ pJFX11\}/(BvuXylA, XK, PPP, gre $3 \Delta)$ & [12] \\
\hline $39 \mathrm{a} \times \mathrm{p} \times \mathrm{p}$ & JUK39a derivative; $\{\mathrm{pPYX} \mathrm{pXp}\} /($ two-copy PirXylA, XK, PPP, gre3 $\Delta$, cyc3 $\Delta$ ) & This work \\
\hline $39 \mathrm{a} \times \mathrm{p} X \mathrm{p} 2415$ & 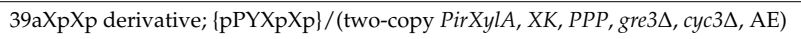 & This work \\
\hline $36 \alpha_{2}$ & $\begin{array}{l}\text { Isolate from chemostat anaerobic and adaptive evolution at a dilution rate of } 0.15 \\
\mathrm{~h}^{-1} \text { on xylose of JUK51a_2 and loss of plasmid pJFX11 }\end{array}$ & This work \\
\hline $39 \mathrm{a}_{2}$ & Isolate from 39aXpXp2415 and loss of plasmid pPYXpXp & This work \\
\hline $39 a_{2} \times p X p$ & $39 \mathrm{a}_{2}$ derivative; $\{\mathrm{pPYX} \mathrm{pXp}\} /($ two-copy $\operatorname{Pir} X y l A, X K, P P P$, gre $3 \Delta$, cyc3 3 ) & This work \\
\hline $39 \mathrm{a}_{2} \mathrm{Xp} \mathrm{Xo}_{\mathrm{o}}$ & 39 $\mathrm{a}_{2}$ derivative; $\{\mathrm{pPYX} \mathrm{pXo}\} /(\operatorname{OrpXylA}, \operatorname{Pir} \mathrm{X} y l A, \mathrm{XK}, \operatorname{PPP}$, gre $3 \Delta$, cyc $3 \Delta)$ & This work \\
\hline $39 \mathrm{a}_{2} \mathrm{Xo}_{\mathrm{o}}$ & $39 \mathrm{a}_{2}$ derivative; $\{\mathrm{pPYXo}\} /(\operatorname{OrpX} \mathrm{X} l A, X K, P P P$, gre $3 \Delta, \operatorname{cyc} 3 \Delta)$ & This work \\
\hline $39 \mathrm{a}_{2} \mathrm{XoXo}$ & 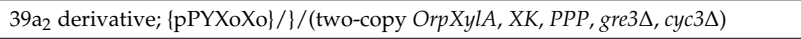 & This work \\
\hline $36 \alpha_{2} \mathrm{XpXpUN}$ & $36 \alpha_{2}$ derivative;NTS2-2::two-copy $\operatorname{PirXylA}$, ura3, XK, PPP, gre3 $\Delta$ & This work \\
\hline $36 \alpha_{2} \mathrm{XoNK}$ & $36 \alpha_{2}$ derivative;NTS2-2::OrpXylA-KanMX4, XK, PPP, gre $3 \Delta$, ura3 $\Delta$ & This work \\
\hline $39 a_{2} \times p X p U N$ & 39 $\mathrm{a}_{2}$ derivative; NTS2-2::two-copy PirXylA, ura3, XK, PPP, gre $3 \Delta$, cyc3 3 & This work \\
\hline $39 \mathrm{a}_{2} \mathrm{XoNK}$ & 39a $\mathrm{a}_{2}$ derivative; NTS2-2::OrpXylA-KanMX4, XK, PPP, gre $3 \Delta$, cyc3 $\Delta$, ura $3 \Delta$ & This work \\
\hline STXQ & Isolate from mating of $36 \alpha_{2} \mathrm{XpXpUN}$ with $39 \mathrm{a}_{2} \mathrm{XoNK}$ & This work \\
\hline \multicolumn{3}{|l|}{ Plasmids } \\
\hline pUG6 & E. coli plasmid with segment loxP-KanMX4-loxP & [30] \\
\hline pJFX11 & YEp, TEF1p-BvuXylA-CYC1t & [12] \\
\hline pPY1 & pPYES2; GAL1p replaced by PGK1p & This work \\
\hline pPYXo & pPY1; PGK1p-OrpXylA-CYC1t & This work \\
\hline pPYXpXp & pPY1; 2 copies of $P G K 1 \mathrm{p}-P i r X y l A-C Y C 1 \mathrm{t}$ in tandem & This work \\
\hline pPYXpXo & pPY1; PGK1p-PirXylA-CYC1t-PGK1p-OrpXylA-CYC1t & This work \\
\hline pPYXoXo & pPY1; 2 copies of PGK1p-OrpXylA-CYC1t in tandem & This work \\
\hline XXUN & $\begin{array}{l}\text { pPYXpXp-based yeast integration plasmid; } 2 \mu \text { and } u r a 3 \text { were replaced with } u r a 3 \\
\text { and NTS2-2 partial fragment }\end{array}$ & This work \\
\hline XoNK & $\begin{array}{l}\text { pUC19-based yeast integration plasmid; } \\
\text { loxP-KanMX4-loxP-pNTS-PGK1p-OrpXylA-CYC1t }\end{array}$ & This work \\
\hline
\end{tabular}

Plasmids pPYXo, pPYXpXo, pPYXoXo and pPYXpXp were individually transformed into 39a, resulting in strains $39 \mathrm{a}_{2} \mathrm{Xo}_{\mathrm{o}} 39 \mathrm{a}_{2} \mathrm{XpXo}, 39 \mathrm{a}_{2} \mathrm{XoXo}$ and $39 \mathrm{a}_{2} \mathrm{XpXp}$, respectively. Plasmids XoNK and XXUN were digested with $S w a I$ and linearized. The linearized fragments were integrated into the genome of $39 \mathrm{a}_{2}$ and $36 \alpha_{2}$ at the NTS2-2 site, individually, resulting in recombinant strains $39 \mathrm{a}_{2}$ XoNK, $39 \mathrm{a}_{2} \mathrm{XpXpUN}, 36 \alpha_{2}$ XoNK and $36 \alpha_{2}$ XpXpUN. For each plasmid transformation, a pool of transformants were generated. The best transformant was isolated based on its cell growth and ethanol production in xylose medium as described in the isolation of 39aXpXp2415. Recombinant strains, $36 \alpha_{2} X p X p U N$ and $39 \mathrm{a}_{2}$ XoNK, were later mated to obtain strain STXQ through screening on SMX agar plates containing $20 \mathrm{~g} \mathrm{~L}^{-1}$ xylose at $\mathrm{pH} 6$ followed by fermentation in SMX medium containing up to $250 \mathrm{~g} \mathrm{~L}^{-1}$ xylose. 


\subsection{Enzyme Activity Assay}

Cells were grown to the exponential phase in SMX medium containing $20 \mathrm{~g} \mathrm{~L}^{-1}$ xylose. After centrifugation, cells were washed twice with chilled distilled water, and then lysed in chilled extraction buffer (100 mM Tris- $\left.\mathrm{HCl}, 10 \mathrm{mM} \mathrm{MgSO}_{4}, \mathrm{pH} 7.5\right)$ by vortex mixing using a Vortex Mixer (Mixer UZUSIO, Tokyo, Japan) with $0.5 \mathrm{mg}$ of $0.5 \mathrm{~mm}$ glass beads (Sigma-Aldirich, Singapore). Protease inhibitor cocktail set V (Merck Millipore, Singapore) was added to inhibit serine and cysteine generated in the lysis process. Cell debris was removed by centrifugation (Microcentrifuge D3024, DR. LAB Technology Hong Kong, Hong Kong, China) at $4000 \times g$ for 10 min at $4{ }^{\circ} \mathrm{C}$, and the crude extract was stored for enzyme activity assay. The protein concentration of the cell extract was determined by the Bradford Assay using a Coomassie Protein Assay Kit (Thermo Scientific, Singapore), and bovine serum albumin (BSA) was used as the standard. Extraction of raw proteins from the yeast strains was performed in duplicate.

The in-vitro XI activity was determined by measuring NADH absorbance using sorbitol dehydrogenase (SDH) (Sigma Aldrich, Singapore). The assay mixture $(1 \mathrm{~mL})$ contained extraction buffer, $0.15 \mathrm{mM}$ NADH, $1 \mathrm{U} \mathrm{SDH}$, and $50 \mu \mathrm{L}$ crude extract. It was equilibrated at $30{ }^{\circ} \mathrm{C}$ for $2 \mathrm{~min}$. The reaction was started by the addition of $\mathrm{D}$-xylose to a final concentration of $500 \mathrm{mM}$. The change of NADH concentration within 3 min was detected using a UV-visible spectrophotometer (Shimadzu, Tokyo, Japan) at wavelength $340 \mathrm{~nm}$, and the specific activity of XI in the recombinant strains was determined [32]. A molar extinction coefficient of $6.25(\mathrm{mM} \mathrm{cm})^{-1}$ at $340 \mathrm{~nm}$ for NADH was used to calculate specific activity. Specific activity was expressed as units per mg protein. One unit of enzyme activity was defined as the amount of enzyme required to oxidize $1 \mu \mathrm{mol}$ of coenzyme/min, under the specified reaction conditions [12].

\subsection{Glucose and Xylose Fermentation by the Recombinant Strains}

The preculture of the evolved engineered strains was prepared by growing them in $40 \mathrm{~mL}$ SMX medium containing $20 \mathrm{~g} \mathrm{~L}^{-1}$ xylose in $100 \mathrm{~mL}$ Erlenmeyer flaks at $200 \mathrm{rpm}$ and $30{ }^{\circ} \mathrm{C}$ for $24 \mathrm{~h}$. The oxygen-limited conditions in the flasks was maintained by capping the flasks with rubber stoppers pierced with a needle to allow the release of $\mathrm{CO}_{2}$. Cells in the exponential phase were harvested by centrifugation (Microcentrifuge D3024, DR. LAB Technology Hong Kong, Hong Kong, China) at $14,000 \times g$ for $1 \mathrm{~min}$. Cell pellets were washed twice and were then inoculated into SM medium supplemented with $20 \mathrm{~g} \mathrm{~L}^{-1}$ xylose with (SMGX) or without $20 \mathrm{~g} \mathrm{~L}^{-1}$ glucose (SMX). The initial optical cell density at $600 \mathrm{~nm}$ (OD600) of the culture was about 2 unless otherwise stated. Fermentation was conducted in $100 \mathrm{~mL}$ Erlenmeyer shaking flasks under oxygen-limited conditions with a working volume of $40 \mathrm{~mL}$ at $200 \mathrm{rpm}$ and $30{ }^{\circ} \mathrm{C}$. The $\mathrm{pH}$ value was adjusted at 5.0-6.0 using $3 \mathrm{M} \mathrm{NaOH}$ during fermentation. All fermentation experiments were performed in duplicate. Samples were taken periodically to measure OD600, sugar and metabolite concentration.

\subsection{Analytical Methods}

Cell densities (OD600) were determined using a UV-visible spectrophotometer (Shimadzu, Tokyo, Japan). Fifty-mL cell cultures with varying OD600 (1-5) were filtered with $0.22 \mu \mathrm{m}$ glass fiber filter membrane (Merck Millipore, Singapore) using Aspirator A-3S (Fisher Scientific, Tokyo, Japan). Cells were washed twice with distilled water, dried at $105^{\circ} \mathrm{C}$ in an oven for $24 \mathrm{~h}$, and then weighed. One OD600 unit corresponded to $0.241 \mathrm{~g} \mathrm{~L}^{-1}$ dry cell weight (DCW). Concentrations of glucose, xylose, xylitol, acetate, glycerol and ethanol produced in fermentation were determined by Agilent 1200 series HPLC system (Agilent Technologies, Santa Clara, CA, USA) equipped with a refractive index detector RID-10A using an Aminex HPX-87H ion exchange column (Bio-Rad Laboratories, Woodinville, WA, USA). The column was eluted at $60^{\circ} \mathrm{C}$ with $5 \mathrm{mM}$ of sulfuric acid as the mobile phase at a flow rate of $0.6 \mathrm{~mL} \mathrm{~min}^{-1}$. 


\subsection{Quantitative Reserve Transcription Polymerase Chain Reaction (RT-PCR)}

Recombinant yeast strains $39 \mathrm{a}_{2} X_{0}, 39 \mathrm{a}_{2} \mathrm{XpXo}, 39 \mathrm{a}_{2} \mathrm{XoX}_{\mathrm{o}}$ and $39 \mathrm{a}_{2} \mathrm{XpXp}$ were individually cultivated in $40 \mathrm{~mL}$ SMX medium containing $20 \mathrm{~g} \mathrm{~L}^{-1}$ xylose under oxygen-limited conditions at $200 \mathrm{rpm}$ and $30^{\circ} \mathrm{C}$. The expression of XI gene transcripts was determined by quantitative reverse transcription polymerase chain reaction (qRT-PCR). Primers for RT-PCR are listed in Table S1. Samples were taken at $24 \mathrm{~h}$, and cells were harvested by centrifuging 2 -mL culture at $14,000 \times g$ and $4{ }^{\circ} \mathrm{C}$ for $1 \mathrm{~min}$. Cell pellets were washed twice using double distilled water and total RNA was isolated by using the E.Z.N.A ${ }^{\mathrm{TM}}$ Yeast RNA Kit (Omega Bio-tek, Norcross, GA, USA). First-strand cDNA was obtained by using the SuperScript ${ }^{\circledR}$ First-Strand Synthesis System for RT-PCR (Invitrogen, Carlsbad, CA, USA). Such cDNA was then used as the template for qRT-PCR using iCycler iQ ${ }^{\mathrm{TM}}$ Real-time PCR Detection System (Bio-Rad Laboratories, Woodinville, WA, USA) and FastStart Universal SYBR Green Master (Roche Applied Science, Penzberg, Germany). The cycle threshold values were calculated with the Optical System Software Version 3.1 (Bio-Rad Laboratories, Woodinville, WA, USA), and the detection threshold over the cycle range was set at 2 to 10. Each PCR was carried out in duplicate. All kits were used under conditions recommended by the manufacturers. The $2^{-\Delta \Delta C t}$ method [33] was used to analyze the relative changes in gene expression using the housekeeping ACT1 gene as the reference.

\subsection{Biomass Hydrolysate Fermentation Using Strain S. cerevisiae STXQ}

The diploid recombinant S. cerevisiae strain STXQ (Table 1) was inoculated into YP medium (10 $\mathrm{g} \mathrm{L}^{-1}$ yeast extract, $20 \mathrm{~g} \mathrm{~L}^{-1}$ peptone, $\mathrm{pH}$ 5.0) containing $132 \mathrm{~g} \mathrm{~L}^{-1}$ xylose or mixture of $162 \mathrm{~g} \mathrm{~L}^{-1}$ glucose and $95 \mathrm{~g} \mathrm{~L}^{-1}$ xylose at an initial OD600 of about 13. Fermentation was conducted in $40 \mathrm{~mL}$ YP medium in $100 \mathrm{~mL}$ shaking flasks under oxygen limited conditions at $200 \mathrm{rpm}$ and $30{ }^{\circ} \mathrm{C}$.

Oil palm empty fruit bunch (OPEFB) hydrolysate was obtained using crude cellulase from Trichoderma reesei Rut-C30 according to the protocols described in our earlier report [34]. OPEFB hydrolysate was sterilized using 0. $22 \mu \mathrm{m}$ filter membrane (Merck Millipore, Singapore) and was supplemented with $7 \mathrm{~g} \mathrm{~L}^{-1}$ yeast extract $2 \mathrm{~g} \mathrm{~L}^{-1}$ peptone, $2 \mathrm{~g} \mathrm{~L}^{-1}\left(\mathrm{NH}_{4}\right)_{2} \mathrm{SO}_{4}, 2.05 \mathrm{~g} \mathrm{~L}^{-1} \mathrm{KH}_{2} \mathrm{PO}_{4}$, and $0.25 \mathrm{~g} \mathrm{~L}^{-1} \mathrm{Na}_{2} \mathrm{HPO}_{4}$. The diploid recombinant $S$. cerevisiae strain STXQ was inoculated into the above OPEFB hydrolysate medium with an initial OD600 about 5. Fermentation was carried out in $40 \mathrm{~mL}$ fermentation medium in $100 \mathrm{~mL}$ shaking flasks under oxygen-limited conditions at $200 \mathrm{rpm}$ and $30{ }^{\circ} \mathrm{C}$ with an initial $\mathrm{pH}$ of 4.48 . Samples were taken periodically for OD600, sugar and metabolite analysis. Experiments were conducted in duplicate.

\section{Results}

\subsection{Expression of XIs with Various Combinations}

XI activities were assayed for 39a 2 recombinant strains with episomal XI genes (Table 2). XI activity of $39 a_{2}$ XoXo was three times higher than that of $39 a_{2}$ XpXp and 2.5 times higher than that of $39 a_{2}$ Xo. Strain $39 \mathrm{a}_{2}$ XoNK presented the highest XI activity among all the yeast strains with integrated XI genes, followed by 39a 2 XpXuN. Quantitative RT-PCR showed that the transcription level of XI gene in the engineered strains significantly increased compared to that in the parent strain 39a $\mathrm{a}_{2}$ (Table 3). In $36 \alpha_{2} \mathrm{XpXpUN}$ and $39 \mathrm{a}_{2} \mathrm{XoNK}$, respective 1.04-fold and 1.41-fold increases in XI gene transcription levels were observed compared to those in $39 \mathrm{a}_{2} \mathrm{XpXp}$ and $39 \mathrm{a}_{2}$ XoXo. Inconsistent XI activity and transcription level were observed. 
Table 2. Specific activity of xylose isomerase in the recombinant strains.

\begin{tabular}{cc}
\hline Strains & Specific Activity $\left(\mathbf{U ~ m g}^{-\mathbf{1}}\right.$ Protein) \\
\hline $39 \mathrm{a}_{2}$ XpXp & $0.10 \pm 0.003$ \\
$39 \mathrm{a}_{2}$ XpXo & $0.11 \pm 0.019$ \\
$39 \mathrm{a}_{2}$ Xo & $0.12 \pm 0.041$ \\
$39 \mathrm{a}_{2}$ XoXo & $0.30 \pm 0.079$ \\
$36 \alpha_{2}$ XpXpUN & $0.11 \pm 0.007$ \\
$36 \alpha_{2}$ XoNK & $0.04 \pm 0.005$ \\
$39 \mathrm{a}_{2}$ XpXpUN & $0.26 \pm 0.004$ \\
$39 \mathrm{a}_{2}$ XoNK & $0.72 \pm 0.006$ \\
\hline
\end{tabular}

The results represent the mean \pm standard deviation of duplicate independent experiments.

Table 3. Fold-change in xylose isomerase (XI) mRNA expression.

\begin{tabular}{|c|c|c|}
\hline \multirow{2}{*}{ Strain } & \multicolumn{2}{|c|}{ Fold-Change $^{a}$} \\
\hline & $\operatorname{PirXylA}$ & OrpXylA \\
\hline $39 a_{2} \times p \times p$ & $50.21(47.81-52.74)$ & nil \\
\hline $39 a_{2} \times p \times o$ & $29.86(28.43-31.36)$ & $11.71(10.62-12.92)$ \\
\hline $39 a_{2} X_{0}$ & nil & $59.71(51.98-68.59)$ \\
\hline $39 a_{2} X_{0} X_{0}$ & nil & $59.71(55.72-64)$ \\
\hline $36 \alpha_{2} \mathrm{XpXpUN}$ & $51.98(49.50-54.60)$ & nil \\
\hline $39 \mathrm{a}_{2} \mathrm{XoNK}$ & nil & $84.45(59.71-119.43)$ \\
\hline
\end{tabular}

a Fold-change of XI mRNA level in the recombinant yeast strains compared to the parent strain $39 \mathrm{a}_{2}$. Results were based on duplicate independent real-time RT-PCR reactions.

\subsection{Glucose and Xylose Fermentation by the Engineered $39 a_{2}$ Strains Harboring Episomal XI Genes}

Fermentation performance of $39 \mathrm{a}_{2}$ recombinant strains with episomal XI genes was tested in SMX medium containing $20 \mathrm{~g} \mathrm{~L}^{-1}$ xylose under oxygen-limited conditions. Apparently, strain 39a $\mathrm{XpXp}$ displayed the fastest xylose utilization rate, followed by $39 a_{2} X_{0} X_{o}$ (Figure 2). Strain $39 a_{2} X_{p} X_{o}$ utilized xylose more slowly than $39 \mathrm{a}_{2} \mathrm{XpXp}$, though it demonstrated almost the same XI activity (Table 2). On the other hand, strain $39 \mathrm{a}_{2} X_{0} X_{0}$ showed a faster xylose utilization rate than strain $39 \mathrm{a}_{2} \mathrm{Xo}_{\mathrm{o}}$, however, the former displayed much higher activity than the latter. On the contrary, xylose utilization results accorded quite well with the results of qRT-PCR analysis showing that strain $39 \mathrm{a}_{2} \mathrm{XpXp}$ had higher XI gene transcription levels than strain $39 \mathrm{a}_{2} \mathrm{Xp} \mathrm{Xo}_{\mathrm{o}}$ (Table 3 ) and a faster xylose utilization rate (Figure 2). However, strains $39 a_{2} X_{0} X_{0}$ and $39 a_{2} X_{0}$ displayed identical XI gene transcription levels (Table 3), almost the same xylose consumption rate (Figure 2) and xylose conversion (Table 4). Interestingly, strain $39 \mathrm{a}_{2} \mathrm{XpXp}$ also exhibited the maximal ethanol yield of $0.472 \mathrm{~g} \mathrm{~g}^{-1}$ (Table 4). Such results suggest that expression of two-copy PirXylA is favorable for xylose alcoholic fermentation when xylose is used as the sole carbon source.
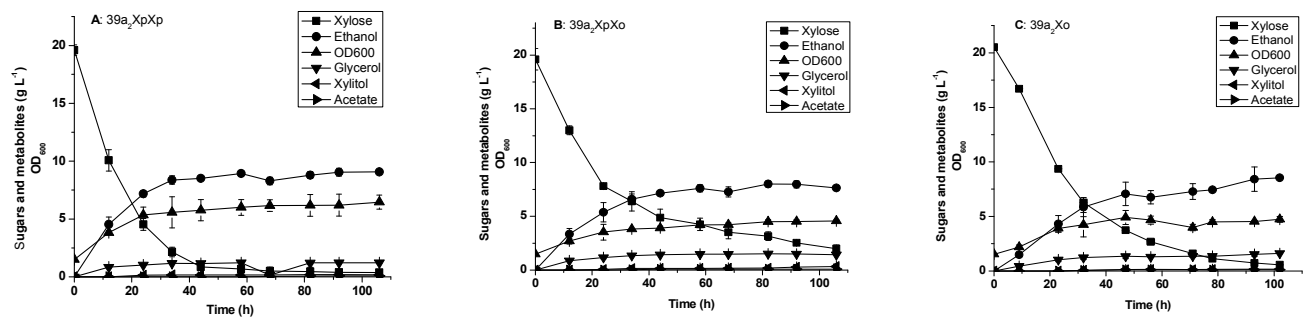

Figure 2. Cont. 

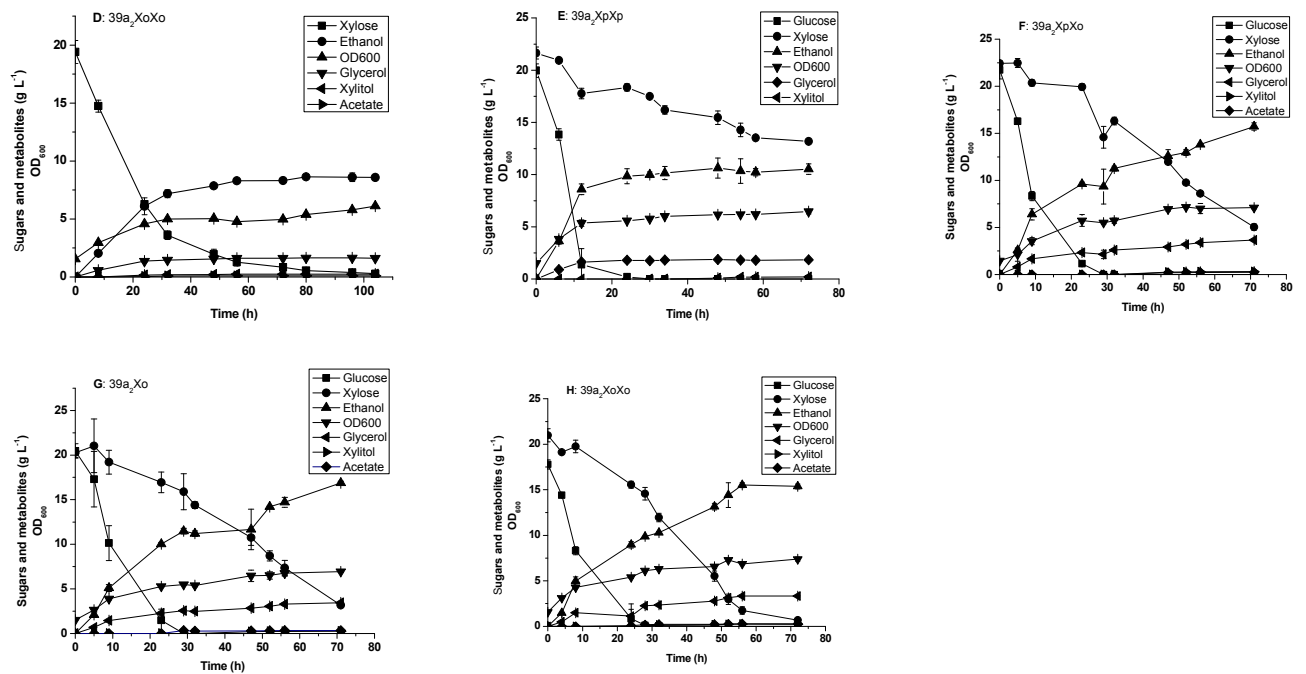

Figure 2. Sugar fermentation under oxygen-limited conditions by the engineered S. cerevisiae strains in SM medium containing $20 \mathrm{~g} \mathrm{~L}^{-1}$ xylose (SMX) or $20 \mathrm{~g} \mathrm{~L}^{-1}$ glucose and $20 \mathrm{~g} \mathrm{~L}^{-1}$ xylose

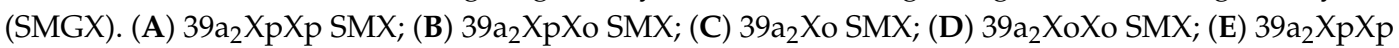
SMGX; (F) 39a $\mathrm{a}_{2}$ XpXo SMGX; (G) 39a $\mathrm{a}_{2}$ X SMGX; (H) 39a $\mathrm{a}_{2} \mathrm{XoXo}_{\mathrm{O}}$ SMGX. The results represent the mean \pm standard deviation of duplicate independent experiments $(p<0.01)$.

Table 4. Glucose and xylose fermentation by recombinant xylose-fermenting yeast strains.

\begin{tabular}{|c|c|c|c|c|c|c|}
\hline Strains & $\begin{array}{l}\text { Initial } \\
\text { glucose } \\
\left(\mathrm{g} \mathrm{L}^{-1}\right)\end{array}$ & $\begin{array}{l}\text { Initial } \\
\text { Xylose } \\
\left(\mathrm{g} \mathrm{L}^{-1}\right)\end{array}$ & $\begin{array}{c}\text { Xylose Conversion } \\
(\%)\end{array}$ & $\begin{array}{l}\text { Ethanol Yield } \\
\qquad\left(\mathrm{g} \mathrm{g}^{-1}\right)\end{array}$ & $\begin{array}{c}\text { Ethanol } \\
\text { Productivity } \\
\left(\mathrm{g} \mathrm{h}^{-1} \mathrm{~L}^{-1}\right)\end{array}$ & $\begin{array}{l}\text { Specific Growth } \\
\text { Rate }\left(h^{-1}\right)\end{array}$ \\
\hline $39 a_{2} \times p \times p{ }^{a}$ & - & 20 & $98 \% \pm 0.004$ & $0.472 \pm 0.013$ & $0.098 \pm 0.004$ & $0.014 \pm 0.001$ \\
\hline $39 a_{2} \times p X_{0}{ }^{a}$ & - & 20 & $89.8 \% \pm 0.011$ & $0.434 \pm 0.017$ & $0.098 \pm 0.004$ & $0.011 \pm 5.89 \times 10^{-6}$ \\
\hline $39 a_{2} X_{0}^{a}$ & - & 20 & $97.3 \% \pm 0.0138$ & $0.428 \pm 0.026$ & $0.084 \pm 0.001$ & $0.011 \pm 0.0003$ \\
\hline $39 \mathrm{a}_{2} \mathrm{XoX}_{0}{ }^{\mathrm{a}}$ & - & 20 & $98.5 \% \pm 0.0057$ & $0.449 \pm 0.038$ & $0.108 \pm 0.001$ & $0.013 \pm 2.29 \times 10^{-5}$ \\
\hline $36 \alpha_{2} \mathrm{XpXpUN}{ }^{\mathrm{a}}$ & - & 20 & $86.4 \% \pm 0.052$ & $0.318 \pm 0.01$ & $0.069 \pm 0.007$ & $0.014 \pm 0.0003$ \\
\hline $36 \alpha_{2} \mathrm{XoNK}^{\mathrm{a}}$ & - & 20 & $6.42 \% \pm 0.057$ & ND & ND & $0.003 \pm 0.0006$ \\
\hline $39 \mathrm{a}_{2} \mathrm{XpXpUN^{ \textrm {a } }}$ & - & 20 & $67.0 \% \pm 0.089$ & $0.398 \pm 0.048$ & $0.067 \pm 0.001$ & $0.013 \pm 0.0002$ \\
\hline $39 \mathrm{a}_{2} \mathrm{XoNK}^{\mathrm{a}}$ & - & 20 & $99.0 \% \pm 0.002$ & $0.368 \pm 0.029$ & $0.107 \pm 0.007$ & $0.0098 \pm 0.0003$ \\
\hline $39 a_{2} \times p \times p{ }^{a}$ & 20 & 20 & $22.0 \% \pm 0.003$ & $0.444 \pm 0.029$ & $0.221 \pm 0.020$ & $0.020 \pm 0.0007$ \\
\hline $39 a_{2} \times p X_{0}{ }^{a}$ & 20 & 20 & $77.5 \% \pm 0.017$ & $0.392 \pm 0.001$ & $0.081 \pm 0.006$ & $0.022 \pm 0.0001$ \\
\hline $39 \mathrm{a}_{2} \mathrm{Xo}^{\mathrm{a}}$ & 20 & 20 & $84.3 \% \pm 0.0007$ & $0.428 \pm 0.01$ & $0.238 \pm 0.003$ & $0.021 \pm 0.0004$ \\
\hline $39 a_{2} X_{o} X_{0}{ }^{a}$ & 20 & 20 & $96.7 \% \pm 0.011$ & $0.449 \pm 0.022$ & $0.213 \pm 0.004$ & $0.021 \pm 0.001$ \\
\hline $36 \alpha_{2} \mathrm{XpXpUN}{ }^{\mathrm{a}}$ & 20 & 20 & $73.8 \% \pm 0.011$ & $0.348 \pm 0.049$ & $0.225 \pm 0.007$ & $0.029 \pm 0.0006$ \\
\hline $36 \alpha_{2} \mathrm{XoNK}^{\mathrm{a}}$ & 20 & 20 & $2.62 \% \pm 0.000$ & $0.390 \pm 0.043$ & $0.222 \pm 0.003$ & $0.016 \pm 0.0013$ \\
\hline $39 a_{2} X p X p U N^{a}$ & 20 & 20 & $25.6 \% \pm 0.097$ & $0.405 \pm 0.049$ & $0.213 \pm 0.002$ & $0.013 \pm 0.0002$ \\
\hline $39 a_{2} X_{0 N K}{ }^{a}$ & 20 & 20 & $97.3 \% \pm 0.006$ & $0.387 \pm 0.002$ & $0.243 \pm 0.003$ & $0.020 \pm 0.0005$ \\
\hline $36 \alpha_{2} \mathrm{XpXpUN}{ }^{b}$ & - & 40 & $75.9 \% \pm 0.041$ & $0.384 \pm 0.033$ & $0.108 \pm 0.011$ & $0.013 \pm 0.0004$ \\
\hline $39 \mathrm{a}_{2} \mathrm{XoNK}^{\mathrm{b}}$ & - & 40 & $81.6 \% \pm 0.004$ & $0.421 \pm 0.004$ & $0.131 \pm 0.000$ & $0.010 \pm 0.0003$ \\
\hline STXQ ${ }^{b}$ & - & 40 & $93.3 \% \pm 0.019$ & $0.393 \pm 0.024$ & $0.146 \pm 0.009$ & $0.017 \pm 0.0002$ \\
\hline STXQ $^{b}$ & - & 132 & $100 \%$ & $0.498 \pm 0.006$ & $1.13 \pm 0.01$ & $0.014 \pm 0.0004$ \\
\hline $\mathrm{STXQ}^{\mathrm{c}}$ & 162 & 95 & $99.27 \% \pm 0.002$ & $0.475 \pm 0.01$ & $5.24 \pm 0.02$ & $0.024 \pm 0.0001$ \\
\hline
\end{tabular}

a Fermentation in SM medium in $72 \mathrm{~h}^{\mathrm{b}}{ }^{\mathrm{b}}$ Fermentation in YP medium in $102 \mathrm{~h} ;{ }^{\mathrm{c}}$ Fermentation in YP medium.

The results represent the mean \pm standard deviation of duplicate independent experiments.

Co-fermentation of $20 \mathrm{~g} \mathrm{~L}^{-1}$ glucose and $20 \mathrm{~g} \mathrm{~L}^{-1}$ xylose was carried out in SM medium under oxygen-limited conditions. It can be seen that for all strains, glucose was almost completely consumed at $24 \mathrm{~h}$ (Figure 2). However, xylose utilization varied greatly for the four engineered $39 \mathrm{a}_{2}$ strains. Noticeably, in the presence of $20 \mathrm{~g} \mathrm{~L}^{-1}$ glucose, strain 39a $\mathrm{XpXp}$ utilized xylose quite slowly and about $22 \%$ xylose was consumed at $72 \mathrm{~h}$ (Table 4 ). On the other hand, xylose utilization was improved to $77.5 \%$ by strain $39 \mathrm{a}_{2} \mathrm{Xp}$ Xo. Moreover, xylose consumption was improved to $84.3 \%$ by strain $39 \mathrm{a}_{2} \mathrm{Xo}_{\mathrm{o}}$ and it was further improved to $97 \%$ by $39 a_{2} X_{o} X_{o}$ (Table 4). It is worth noting that strain $39 a_{2} X_{o} X_{0}$ presented the highest ethanol yield $\left(0.449 \mathrm{~g} \mathrm{~g}^{-1}\right)$. The above results suggest that the expression of two-copy of OrpXylA is beneficial for glucose and xylose co-fermentation. 


\subsection{Glucose and xylose Fermentation by the Engineered Yeast Strains Harboring Integrated XI Genes}

Fermentation performance of $39 \mathrm{a}_{2}$ recombinant strains with integrated XI genes was tested in SM medium containing $20 \mathrm{~g} \mathrm{~L}^{-1}$ xylose (SMX) or $20 \mathrm{~g} \mathrm{~L}^{-1}$ glucose and $20 \mathrm{~g} \mathrm{~L}^{-1}$ xylose (SMGX) under oxygen-limited conditions (Figure 3). In SMX fermentation, the specific growth rate of $36 \alpha_{2} X \mathrm{pXpUN}$ on xylose was $0.014 \mathrm{~h}^{-1}$, much higher than that of $36 \alpha_{2}$ XoNK $\left(0.003 \mathrm{~h}^{-1}\right)$, whereas xylose conversion by strain $39 \mathrm{a}_{2}$ XoNK was $99.0 \%$, much higher than that by $39 \mathrm{a}_{2}$ XpXpUN (67.0\%) (Table 4 ). In SMGX fermentation, the specific growth rate of $36 \alpha_{2} \mathrm{XpXpUN}$ on xylose was $0.029 \mathrm{~h}^{-1}$, much higher than that of $36 \alpha_{2}$ XoNK $\left(0.016 \mathrm{~h}^{-1}\right)$, whereas xylose conversion by strain $39 \mathrm{a}_{2}$ XoNK was $97.30 \%$, much higher than that by 39a $\mathrm{a}_{2} \mathrm{XPXUN}$ (73.8\%) (Table 4). In both SMX and SMGX fermentation, strain $36 \alpha_{2}$ XpXpUN presented the best cell growth, whereas strain $39 \mathrm{a}_{2}$ XoNK displayed the best xylose conversion. Furthermore, strain $39 \mathrm{a}_{2}$ XoNK exhibited the highest ethanol productivity in both SMX and SMGX fermentation. Despite the possible XI gene copy number variation in these strains, the above results demonstrated that the elimination of respiration was favorable for xylose fermentation, which corroborated quite well with previous reports $[12,14]$. Strains $36 \alpha_{2} X p X p U N$ and $39 \mathrm{a}_{2}$ XoNK were therefore selected for mating to generate the diploid recombinant strain STXQ to attain good cell growth and xylose fermentation.

\subsection{Glucose and xylose Fermentation by Diploid Recombinant Strain STXQ}

Fermentation performance of STXQ was tested in YP medium containing $40 \mathrm{~g} \mathrm{~L}^{-1}$ xylose under oxygen-limited conditions. As expected, strain STXQ inherited the advantages of both parent strains, $36 \alpha_{2}$ XpXpUN and 39a $\mathrm{a}_{2}$ XNK. It presented 93.3\% xylose conversion and a specific growth rate of $0.017 \mathrm{~h}^{-1}$; both were higher than those of its parent strains (Table 4). In addition, ethanol productivity was greatly improved (Figure 3, Table 4). A very minimum amount of glycerol was produced by STXQ, although glycerol production was notable for the respiration-deficient parent strain $39 \mathrm{a}_{2}$ XoNK (Figure 3). Moreover, production of xylitol and acetate was almost undetectable.
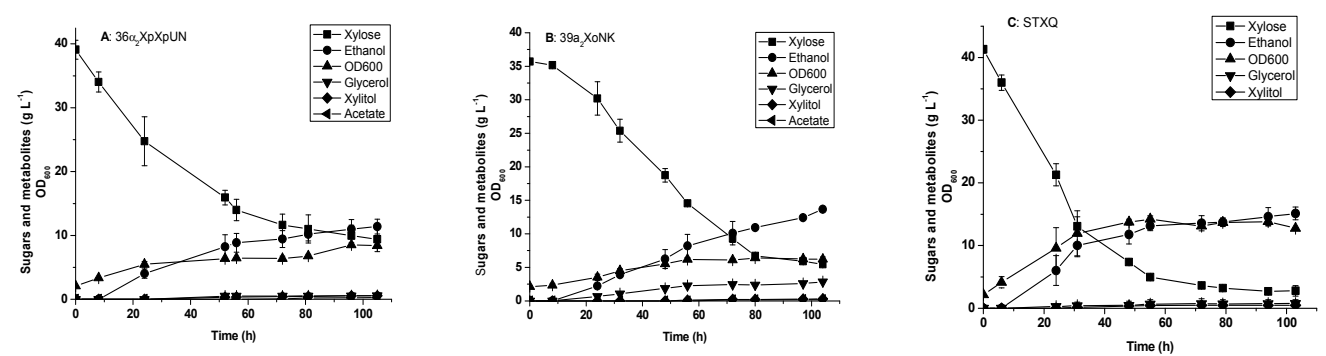

Figure 3. Xylose fermentation in YPX medium containing $40 \mathrm{~g} \mathrm{~L}^{-1}$ xylose under oxygen-limited conditions. (A) $36 \alpha_{2} \mathrm{XpXpUN;} \mathrm{(B)} \mathrm{39a_{2 } X o N K ; ~ ( C ) ~ S T X Q . ~ T h e ~ r e s u l t s ~ r e p r e s e n t ~ t h e ~ m e a n ~} \pm$ standard deviation of duplicate independent experiments $(p<0.01)$.

Fermentation performance of strain STXQ was further invested in YP medium containing high-concentration sugar. With an initial OD600 of about 13, strain STXQ consumed 100\% xylose in fermenting $132 \mathrm{~g} \mathrm{~L}^{-1}$ xylose and produced $65.8 \mathrm{~g} \mathrm{~L}^{-1}$ ethanol at $46 \mathrm{~h}$. The corresponding ethanol yield was $0.498 \mathrm{~g} \mathrm{~g}^{-1}$ (Figure 4A, Table 4). In fermentation of $162 \mathrm{~g} \mathrm{~L}^{-1}$ glucose and $95 \mathrm{~g} \mathrm{~L}^{-1}$ xylose with about the same initial OD600, more than 99\% glucose and xylose were co-utilized within $23 \mathrm{~h}$ (Figure 4B, Table 4). Ethanol titer reached $120.6 \mathrm{~g} \mathrm{~L}^{-1}$ corresponding to an ethanol volumetric productivity of $5.26 \mathrm{~g} \mathrm{~L}^{-1} \mathrm{~h}^{-1}$. These are so far the highest values compared to those reported in the literature. The above results indicate that the strain development strategy elaborated in this study is efficient in generating a robust $S$. cerevisiae strain with improved xylose fermentation capabilities. 

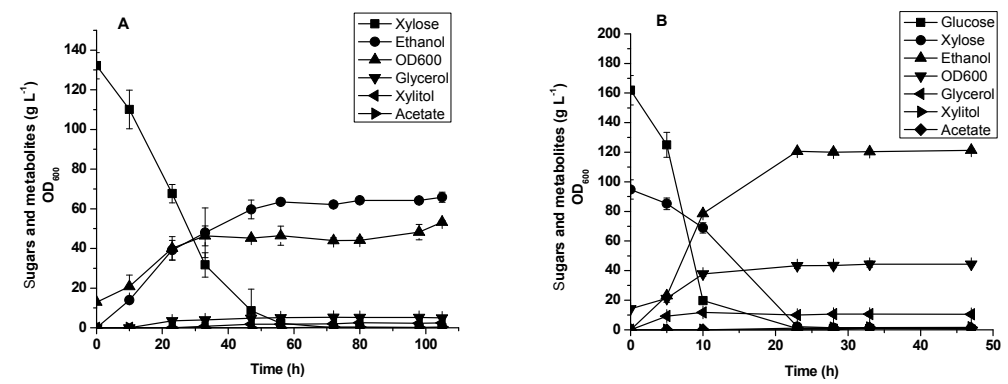

Figure 4. High-titer sugar fermentation under oxygen-limited conditions by strain STXQ in YP media. (A) Xylose fermentation in YPX medium containing $132 \mathrm{~g} \mathrm{~L}^{-1}$ xylose; (B) Glucose and xylose co-fermentation in YPGX medium containing $162 \mathrm{~g} \mathrm{~L}^{-1}$ glucose and $95 \mathrm{~g} \mathrm{~L}^{-1}$ xylose. The results represent the mean \pm standard deviation of duplicate independent experiments $(p<0.01)$.

\subsection{Oil Palm Empty Fruit Bunch Hydrolysate Fermentation by Diploid Recombinant Strain STXQ}

Fermentation performance of strain STXQ was further tested in OPEFB hydrolysate containing $41.81 \mathrm{~g} \mathrm{~L}^{-1}$ glucose, $30.00 \mathrm{~g} \mathrm{~L}^{-1}$ xylose, $7 \mathrm{~g} \mathrm{~L}^{-1}$ yeast extract, $2 \mathrm{~g} \mathrm{~L}^{-1}$ peptone, $2 \mathrm{~g} \mathrm{~L}^{-1}(\mathrm{NH} 4)_{2} \mathrm{SO}_{4}$, $2.05 \mathrm{~g} \mathrm{~L}^{-1} \mathrm{KH}_{2} \mathrm{PO}_{4}$, and $0.25 \mathrm{~g} \mathrm{~L}^{-1} \mathrm{Na}_{2} \mathrm{HPO}_{4}$ under oxygen-limited conditions with an initial OD600 of about 10 . Strain STXQ consumed $95.3 \%$ glucose and $88.9 \%$ xylose (Figure 5 ). The $\mathrm{pH}$ value decreased from 4.48 to 4.00 within $72 \mathrm{~h}$. Strain STXQ consumed 94.0\% total sugar from the OPEFB hydrolysate without detoxification. The specific cell growth rate $\left(\mu_{\max }\right)$ reached $0.013 \mathrm{~h}^{-1}$ and the ethanol yield was $0.420 \mathrm{~g} \mathrm{~g}^{-1}$. Glucose was quickly consumed, and glucose-xylose co-fermentation was clearly observed within $24 \mathrm{~h}$. Subsequently, ethanol concentration kept increasing with almost the sole consumption of xylose until it reached the final titer of $28.4 \mathrm{~g} \mathrm{~L}^{-1}$ at $72 \mathrm{~h}$.

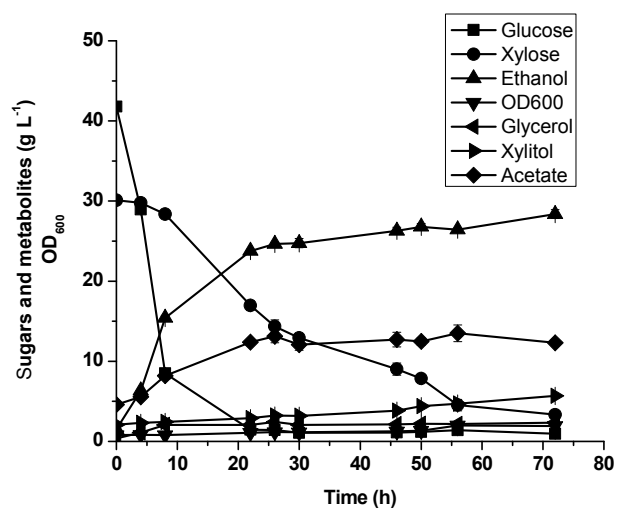

Figure 5. Sugar fermentation under oxygen-limited conditions by strain STXQ in oil palm empty fruit bunch hydrolysate supplemented with $7 \mathrm{~g} \mathrm{~L}^{-1}$ yeast extract, $2 \mathrm{~g} \mathrm{~L}^{-1}$ peptone, $2 \mathrm{~g} \mathrm{~L}^{-1}(\mathrm{NH} 4)_{2} \mathrm{SO}_{4}$, $2.05 \mathrm{~g} \mathrm{~L}^{-1} \mathrm{KH}_{2} \mathrm{PO}_{4}$, and $0.25 \mathrm{~g} \mathrm{~L}^{-1} \mathrm{Na}_{2} \mathrm{HPO}_{4}$. The results represent the mean \pm standard deviation of duplicate independent experiments $(p<0.01)$.

\section{Discussion}

Episomal plasmids containing OrpXylA, PirXylA and OrpXylA in tandem, two-copy PirXylA and two-copy OrpXylA expression cassettes (Figure 1) were transformed into the background strain 39a individually. Among all the $39 \mathrm{a}_{2}$ strains harboring episomal XI genes, strain $39 \mathrm{a}_{2} \mathrm{XpXp}$ presented the fastest rate of xylose utilization when xylose was used as the sole carbon source. However, it did not exhibit the highest XI activity and transcription level (Tables 2 and 3). Inconsistent XI activity and transcription level in recombinant xylose-fermenting $S$. cerevisiae strain was reported and it could be due to rearrangement of pentose phosphate pathway (PPP) genes, decreased glycolysis activity, repressed respiration activity, and enhanced gluconeogenesis [35]. Besides XI activity, the 
enhanced xylose utilization and fermentation could be associated with the elevated expression of sugar transporter genes, non-oxidative pentose phosphate pathway (PPP) genes such as TAL1, TKL1, RKI1, and RPE1 and xylulokinase gene, XKS1 [19,20,25,36].

For glucose and xylose co-fermentation, strain $39 \mathrm{a}_{2} \mathrm{XoXo}_{0}$ presented the best glucose and xylose co-utilization (Figure 2 ) and exhibited the highest xylose conversion (96.7\%) (Table 4). S. cerevisiae does not contain specific xylose transporters. Xylose was therefore transported by glucose transporters. Xylose affinity for the glucose transporters was very low at a high glucose concentration; however, it could increase to a similar level of glucose affinity at low glucose concentration $[19,20]$. As a result, diauxic lag is still a practical problem associated with mixed sugar utilization by xylose-fermenting yeasts. However, the diauxic growth was not significant for strains expressing OrpXylA, 39a ${ }_{2} X_{0}$ and $39 \mathrm{a}_{2} \mathrm{XoX}_{\mathrm{O}}$ (Figure 2). The above results and analysis suggest that expression of OrpXylA is beneficial for glucose and xylose co-fermentation. This is consistent with a previous report [37].

Chromosomal integration of the XI gene into the $S$. cerevisiae genome has received a significant amount of attention in recent years $[25,26]$. It allows the recombinant strain to retain its physiological characteristics in nonselective medium. In the present study, multiple copies of XI genes were integrated at the $18 \mathrm{~S}$ rDNA sites based on random homologous recombination. Such genome integration led to stable recombinant yeast strains (Figure S1) and boosted XI activity to $0.72 \mathrm{U} \mathrm{mg}^{-1}$ protein in $39 \mathrm{a}_{2} \mathrm{XoNK}$ (Table 2). Such improvement might be associated with the multiple copies of XI integrated in the yeast genome [25]. This further led to high XI transcription levels (Table 3), high xylose conversion and ethanol production (Table 4). Such results accorded quite well with earlier reports $[25,26,36]$. Notably, among these strains, 39a $\mathrm{a}_{2}$ strains with integrated XI genes presented higher XI activity and transcription level than $36 \alpha_{2}$ strains (Tables 2 and 3). This further confirmed that the elimination of respiration was favorable for xylose fermentation [12,14].

S. cerevisiae strains are regarded as industrial working horses for ethanol production owing to their high ethanol titer and sugar tolerance. Mating is one of the traditional yeast breeding methods to develop improved S. cerevisiae strains without genetic modifications [38]. Through strain mating, robust diploid S. cerevisiae strains were developed for enhanced xylose-fermentation and inhibitor resistance [23,24]. In the present work, a recombinant diploid S. cerevisiae strain STXQ was obtained by mating respiration-dependent strain $36 \alpha_{2} X p X p U N$ with the respiration-deficient strain $39 a_{2} X o N K$. Such strain mating enabled strain STXQ to present improved cell growth, xylose utilization and ethanol production (Figure 4, Table 4).

For glucose-xylose co-fermentation by engineered laboratory S. cerevisiae strains, higher ethanol concentration of $\sim 60 \mathrm{~g} \mathrm{~L}^{-1}$ was reported by Ho et al. [39] (Table 5). An ethanol titer of $47.5 \mathrm{~g} \mathrm{~L}^{-1}$ was obtained by recombinant S. cerevisiae RWB218 expressing PirXylA [40]. About $53 \mathrm{~g} \mathrm{~L}^{-1}$ ethanol titer was reported by Diao and his colleagues using the diploid recombinant $S$. cerevisiae strain CIBTS0735 [22]. Demeke et al. obtained an inhibitor-resistant recombinant $S$. cerevisiae through metabolic engineering and adaptive evolution [18]. It utilized glucose and xylose rapidly with ethanol titer up to $46 \mathrm{~g} \mathrm{~L}^{-1}$ and ethanol productivity of $2.58 \mathrm{~g} \mathrm{~L}^{-1} \cdot \mathrm{h}^{-1}$. This is the highest volumetric ethanol productivity reported to-date in the literature. More recently, about $58 \mathrm{~g} \mathrm{~L}^{-1}$ ethanol titer was obtained by a diploid recombinant yeast strain LF1 developed from a wild-type S. cerevisiae strain in YP medium [25]. Strain STXQ yielded $65.8 \mathrm{~g} \mathrm{~L}^{-1}$ ethanol with an ethanol yield of $0.50 \mathrm{~g} \mathrm{~g}^{-1}$ at $56 \mathrm{~h}$ in YPX medium containing $132 \mathrm{~g} \mathrm{~L}^{-1}$ xylose (Figure 4A, Table 4). Further glucose-xylose co-fermentation produced $120.6 \mathrm{~g} \mathrm{~L}^{-1}$ ethanol with an ethanol yield of $0.48 \mathrm{~g} \mathrm{~g}^{-1}$ at $23 \mathrm{~h}$ in $\mathrm{YP}$ medium containing $162 \mathrm{~g} \mathrm{~L}^{-1}$ glucose and $95 \mathrm{~g} \mathrm{~L}^{-1}$ xylose. The corresponding volumetric ethanol productivity reached $5.24 \mathrm{~g} \mathrm{~L}^{-1} \cdot \mathrm{h}^{-1}$. (Figure $4 \mathrm{~B}$, Table 4). Both ethanol titer and volumetric productivity far exceeded the results in previous reports. 
Table 5. Comparison of fermentation performance of engineered xylose-fermenting S. cerevisiae.

\begin{tabular}{|c|c|c|c|c|c|c|c|c|}
\hline Strain & Description & Inoculum Biomass (g DCW $\mathrm{L}^{-1}$ ) & $\begin{array}{l}\text { Initial } \\
\text { Glucose } \\
\left(\mathrm{g} \mathrm{L}^{-1}\right)\end{array}$ & $\begin{array}{l}\text { Initial } \\
\text { Xylose } \\
\left(\mathrm{g} \mathrm{L}^{-1}\right)\end{array}$ & $\begin{array}{l}\text { Final } \\
\text { Ethanol } \\
\left(\mathrm{g} \mathrm{L}^{-1}\right)\end{array}$ & $\begin{array}{l}\text { Ethanol } \\
\text { Yield (g } \\
\left.\mathrm{g}^{-1}\right)\end{array}$ & $\begin{array}{c}\text { Volumetric } \\
\text { Ethanol } \\
\text { Productivity } \\
\left(\mathrm{g} \mathrm{L}^{-1} \cdot \mathrm{h}^{-1}\right)\end{array}$ & Reference \\
\hline \multirow[t]{2}{*}{ CIBTS0735 } & $\begin{array}{l}\text { PirXylA; XKS1; PPP; ciGXF1; adaptive } \\
\text { evolution }\end{array}$ & $\begin{array}{l}\text { Rich medium, initial inoculum size } \\
\text { at } 0.63 \mathrm{~g}^{\circ} \mathrm{DCW} \mathrm{L}^{-1}\end{array}$ & & 40 & 17.47 & 0.44 & 1.09 & [18] \\
\hline & & $\begin{array}{l}\text { Rich medium, initial inoculum size } \\
\text { at } 0.63 \mathrm{~g} \mathrm{DCW} \mathrm{L}^{-1}\end{array}$ & 80 & 40 & 53 & 0.45 & 2.22 & \\
\hline RWB218 & 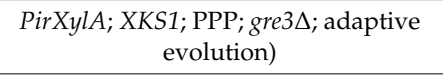 & $\begin{array}{l}\text { defined synthetic medium, initial } \\
\text { inoculum size at } 1.1 \mathrm{~g} \mathrm{DCW} \mathrm{L}^{-1}\end{array}$ & 100 & 25 & 47.5 & 0.38 & 1.98 & [40] \\
\hline \multirow[t]{2}{*}{1400 (pLNH32) } & $\mathrm{XR} ; \mathrm{XDH}$ XK; adaptive evolution & Rich medium; OD 40-45 & 50 & & 24 & 0.48 & 0.52 & [39] \\
\hline & & Rich medium; OD 40-45 & 80 & 40 & 60 & 0.45 & 1.3 & \\
\hline H31-A3-AL ${ }^{C S}$ & $\begin{array}{l}\text { PirXylA; XKS1; PPP; gre3 } \Delta \text {; adaptive } \\
\text { evolution }\end{array}$ & $\begin{array}{l}\text { Defined medium;initial inoculum size } \\
\text { at } 0.05 \mathrm{~g} \mathrm{DCW} \mathrm{L}^{-1}\end{array}$ & & 40 & 16.4 & 0.41 & 0.55 & [28] \\
\hline GS1.11-26 & $\begin{array}{l}\text { cpXylA; XKS1; PPP; HXT7; AraT; AraA; } \\
\text { AraB; AraD; TAL2; TKL2 mutagenesis; } \\
\text { genome shuffling; adaptive evolution }\end{array}$ & $\begin{array}{l}\text { Rich medium; initial inoculum size } \\
\text { at } 1.3 \mathrm{~g} \text { DCW L } \mathrm{L}^{-1}\end{array}$ & 36 & 37 & 33.6 & 0.46 & 2.58 & [18] \\
\hline LF1 & $\begin{array}{c}\text { Ru-XylA, XKS1, PPP, } \\
\text { gre3::MGT05196 } \\
\text { evolution }\end{array}$ & $\begin{array}{l}\text { Rich medium, initial inoculum size } \\
\text { at } 1.00 \mathrm{~g} \mathrm{DCW} \mathrm{L}^{-1}\end{array}$ & 80 & 42 & 58.0 & 0.47 & 3.60 & [25] \\
\hline \multirow[t]{2}{*}{ STXQ } & 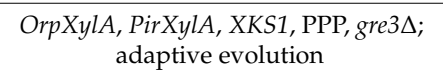 & $\begin{array}{l}\text { Rich medium, initial inoculum size } \\
\text { at } 3.13 \mathrm{~g} \mathrm{DCW} \mathrm{L}^{-1}\end{array}$ & & 132 & 65.8 & 0.50 & 1.13 & This study \\
\hline & & $\begin{array}{l}\text { Rich medium, initial inoculum size } \\
\text { at } 3.43 \mathrm{~g} \mathrm{DCW} \mathrm{L}^{-1}\end{array}$ & 162 & 95 & 120.6 & 0.48 & 5.24 & This study \\
\hline
\end{tabular}


The OPEFB hydrolysate fermentation result demonstrated that strain STXQ could co-ferment glucose and xylose without detoxification, with $95.3 \%$ glucose conversion and $88.9 \%$ xylose conversion at $72 \mathrm{~h}$ (Figure 5). Ethanol titer reached $28.4 \mathrm{~g} \mathrm{~L}^{-1}$ at $72 \mathrm{~h}$ with an ethanol yield of $0.420 \mathrm{~g} \mathrm{~g}^{-1}$. Strain STXQ has potential in the conversion of lignocellulosic biomass hydrolysate to ethanol. These results suggest that the strain development protocols outlined in this study are effective in obtaining robust xylose-fermenting yeast strains for industrial applications.

\section{Conclusions}

A recombinant haploid strain containing plasmids harboring two-copy PirXylA presented the best xylose utilization among the engineered yeast strains harboring episomal XI genes when xylose was used as the sole carbon source. On the other hand, the strain containing plasmids with two-copy OrpXylA exhibited the best glucose and xylose co-fermentation. Respiration-deficient $39 \mathrm{a}_{2}$ strains harboring the $\mathrm{OrpXylA}$ gene were favorable for xylose fermentation and glucose-xylose co-fermentation in the engineered yeast strains. Chromosome integration of XI genes in S. cerevisiae resulted in high XI activity, high XI transcription levels, and improved xylose fermentation. Mating the respiration-efficient strain $36 \alpha_{2}$ XpXpUN with the respiration-deficient strain $39 \mathrm{a}_{2} \mathrm{XoNK}$ resulted in a diploid recombinant S. cerevisiae strain STXQ with enhanced cell growth and xylose fermentation. Strain STXQ demonstrated superior glucose and xylose co-fermentation performance. It produced $120.6 \mathrm{~g} \mathrm{~L}^{-1}$ ethanol with a volumetric productivity of $5.24 \mathrm{~g} \mathrm{~L}^{-1} \mathrm{~h}^{-1}$, the highest among those reported to-date. Such superior performance by strain STXQ is largely associated with its development process, in particular with strain adaptive evolution, XI gene chromosome integration and strain mating.

Supplementary Materials: The following are available online at http://www.mdpi.com/2311-5637/4/3/59/s1.

Author Contributions: Conceptualization, A.G. and T.L; Methodology, T.L.; Investigation, T.L.; Data Curation, T.L. and S.H.; Writing-Original Draft Preparation, T.L.; Writing-Review \& Editing, A.G.; Supervision, A.G.; Project Administration, A.G.; Funding Acquisition, A.G.

Funding: This research was funded by the Science and Engineering Research Council of the Agency for Science Technology and Research (A*STAR) Singapore, grant number 092-139-0035.

Acknowledgments: The authors would like to thank Ngee Ann Polytechnic for providing the internship opportunities to Tingting Liu and Shuangcheng Huang during the period of this project.

Conflicts of Interest: The authors declare no conflict of interest.

\section{References}

1. Somerville, C.; Youngs, H.; Taylor, C.; Davis, S.C.; Long, S.P. Feedstocks for lignocellulosic biofuels. Science 2010, 329, 790-792. [CrossRef] [PubMed]

2. Miao, Z.; Grift, T.E.; Hansen, A.C.; Ting, K.C. An overview of lignocellulosic biomass feedstock harvest, processing and supply for biofuel production. Biofuels 2013, 4, 5-8. [CrossRef]

3. Fatma, S.; Hameed, A.; Noman, M.; Ahmed, T.; Shahid, M.; Tariq, M.; Sohail, I.; Tabassum, R. Lignocellulosic biomass: A sustainable bioenergy source for the future. Protein Pept. Lett. 2018, 25, 148-163. [CrossRef] [PubMed]

4. Moyses, D.N.; Reis, V.C.; de Almeida, J.R.; de Moraes, L.M.; Torres, F.A. Xylose fermentation by Saccharomyces cerevisiae: Challenges and prospects. Int. J. Mol. Sci. 2016, 17, 207. [CrossRef] [PubMed]

5. Li, Y.C.; Gou, Z.X.; Zhang, Y.; Xia, Z.Y.; Tang, Y.Q.; Kida, K. Inhibitor tolerance of a recombinant flocculating industrial Saccharomyces cerevisiae strain during glucose and xylose co-fermentation. Braz. J. Microbiol. 2017, 48, 798-800. [CrossRef] [PubMed]

6. Hahn-Hägerdal, B.; Karhumaa, K.; Jeppsson, M.; Gorwa-Grauslund, M.F. Metabolic engineering for pentose utilization in Saccharomyces cerevisiae. Adv. Biochem. Eng. Biotechnol. 2007, 108, 147-177. [CrossRef] [PubMed]

7. Madhavan, A.; Srivastava, A.; Kondo, A.; Bisaria, V.S. Bioconversion of lignocellulose-derived sugars to ethanol by engineered Saccharomyces cerevisiae. Crit. Rev. Biotechnol. 2012, 32, 22-48. [CrossRef] [PubMed]

8. Zhang, G.C.; Liu, J.J.; Kong, I.I.; Kwak, S.; Jin, Y.S. Combining C6 and C5 sugar metabolism for enhancing microbial bioconversion. Curr. Opin. Chem. Biol. 2015, 29, 49-57. [CrossRef] [PubMed] 
9. Kwak, S.; Jin, Y.S. Production of fuels and chemicals from xylose by engineered Saccharomyces cerevisiae: A review and perspective. Microb. Cell Factories 2017, 16, 82. [CrossRef] [PubMed]

10. Hou, J.; Qiu, C.; Shen, Y.; Li, H.; Bao, X. Engineering of Saccharomyces cerevisiae for the efficient co-utilization of glucose and xylose. FEMS Yeast Res. 2017, 17. [CrossRef] [PubMed]

11. Kuyper, M.; Hartog, M.M.; Toirkens, M.J.; Almering, M.J.; Winkler, A.A.; van Dijken, J.P.; Pronk, J.T. Metabolic engineering of a xylose-isomerase-expressing Saccharomyces cerevisiae strain for rapid anaerobic xylose fermentation. FEMS Yeast Res. 2005, 5, 399-409. [CrossRef] [PubMed]

12. Peng, B.; Huang, S.; Liu, T.; Geng, A. Bacterial xylose isomerases from the mammal gut Bacteroidetes cluster function in Saccharomyces cerevisiae for effective xylose fermentation. Microb. Cell Factories 2015, 14, 70. [CrossRef] [PubMed]

13. Johansson, B.; Hahn-Hägerdal, B. The non-oxidative pentose phosphate pathway controls the fermentation rate of xylulose but not of xylose in Saccharomyces cerevisiae TMB3001. FEMS Yeast Res. 2002, 2, 277-282. [PubMed]

14. Peng, B.; Shen, Y.; Li, X.; Chen, X.; Hou, J.; Bao, X. Improvement of xylose fermentation in respiratory-deficient xylose-fermenting Saccharomyces cerevisiae. Metab. Eng. 2012, 14, 9-18. [CrossRef] [PubMed]

15. Lee, S.H.; Kodaki, T.; Park, Y.C.; Seo, J.H. Effects of NADH-preferring xylose reductase expression on ethanol production from xylose in xylose-metabolizing recombinant Saccharomyces cerevisiae. J. Biotechnol. 2012, 158, 184-191. [CrossRef] [PubMed]

16. Sonderegger, M.; Sauer, U. Evolutionary engineering of Saccharomyces cerevisiae for anaerobic growth on xylose. Appl. Environ. Microbiol. 2003, 69, 1990-1998. [CrossRef] [PubMed]

17. Scalcinati, G.; Otero, J.M.; Vleet, J.R.; Jeffries, T.W.; Olsson, L.; Nielsen, J. Evolutionary engineering of Saccharomyces cerevisiae for efficient aerobic xylose consumption. FEMS Yeast Res. 2012, 12, 582-597. [CrossRef] [PubMed]

18. Demeke, M.M.; Dietz, H.; Li, Y.; Foulquie-Moreno, M.R.; Mutturi, S.; Deprez, S.; Den Abt, T.; Bonini, B.M.; Liden, G.; Dumortier, F.; et al. Development of a D-xylose fermenting and inhibitor tolerant industrial Saccharomyces cerevisiae strain with high performance in lignocellulose hydrolysates using metabolic and evolutionary engineering. Biotechnol. Biofuels 2013, 6, 89. [CrossRef] [PubMed]

19. Sedlak, M.; Ho, N.W. Characterization of the effectiveness of hexose transporters for transporting xylose during glucose and xylose co-fermentation by a recombinant Saccharomyces yeast. Yeast 2004, 21, 671-684. [CrossRef] [PubMed]

20. Runquist, D.; Hahn-Hagerdal, B.; Radstrom, P. Comparison of heterologous xylose transporters in recombinant Saccharomyces cerevisiae. Biotechnol. Biofuels 2010, 17, 3-5. [CrossRef] [PubMed]

21. Goncalves, D.L.; Matsushika, A.; de Sales, B.B.; Goshima, T.; Bon, E.P.; Stambuk, B.U. Xylose and xylose/glucose co-fermentation by recombinant Saccharomyces cerevisiae strains expressing individual hexose transporters. Enzyme Microb. Technol. 2014, 63, 13-20. [CrossRef] [PubMed]

22. Diao, L.; Liu, Y.; Qian, F.; Yang, J.; Jiang, Y.; Yang, S. Construction of fast xylose-fermenting yeast based on industrial ethanol-producing diploid Saccharomyces cerevisiae by rational design and adaptive evolution. BMC Biotechnol. 2013, 13, 110. [CrossRef] [PubMed]

23. Demeke, M.M.; Dumortier, F.; Li, Y.; Broeckx, T.; Foulquié-Moreno, M.R.; Thevelein, J.M. Combining inhibitor tolerance and D-xylose fermentation in industrial Saccharomyces cerevisiae for efficient lignocellulose-based bioethanol production. Biotechnol. Biofuels 2013, 6, 120. [CrossRef] [PubMed]

24. Kim, S.R.; Lee, K.S.; Kong, I.I.; Lesmana, A.; Lee, W.H.; Seo, J.H.; Kweon, D.H.; Jin, Y.S. Construction of an efficient xylose-fermenting diploid Saccharomyces cerevisiae strain through mating of two engineered haploid strains capable of xylose assimilation. J. Biotechnol. 2013, 164, 105-111. [CrossRef] [PubMed]

25. Li, H.; Shen, Y.; Wu, M.; Hou, J.; Jiao, C.; Li, Z.; Liu, X.; Bao, X. Engineering a wild-type diploid Saccharomyces cerevisiae strain for second-generation bioethanol production. Bioresour. Bioprocess. 2016, 3, 51. [CrossRef] [PubMed]

26. Tanino, T.; Hotta, A.; Ito, T.; Ishii, J.; Yamada, R.; Hasunuma, T.; Ogino, C.; Ohmura, N.; Ohshima, T.; Kondo, A. Construction of a xylose-metabolizing yeast by genome integration of xylose isomerase gene and investigation of the effect of xylitol on fermentation. Appl. Microbiol. Biotechnol. 2010, 88, 1215-1221. [CrossRef] [PubMed]

27. Bamba, T.; Hasunuma, T.; Kondo, A. Disruption of PHO13 improves ethanol production via the xylose isomerase pathway. AMB Express 2016, 6, 4. [CrossRef] [PubMed] 
28. Zhou, H.; Cheng, J.S.; Wang, B.L.; Fink, G.R.; Stephanopoulos, G. Xylose isomerase overexpression along with engineering of the pentose phosphate pathway and evolutionary engineering enable rapid xylose utilization and ethanol production by Saccharomyces cerevisiae. Metab. Eng. 2012, 14, 611-622. [CrossRef] [PubMed]

29. Ko, J.K.; Um, Y.; Woo, H.M.; Kim, K.H.; Lee, S.M. Ethanol production from lignocellulosic hydrolysates using engineered Saccharomyces cerevisiae harboring xylose isomerase-based pathway. Bioresour. Technol. 2016, 209, 290-296. [CrossRef] [PubMed]

30. Güldener, U.; Heck, S.; Fiedler, T.; Beinhauer, J.; Hegemann, J.H. A new efficient gene disruption cassette for repeated use in budding yeast. Nucleic Acids Res. 1996, 24, 2519-2524. [CrossRef] [PubMed]

31. Gietz, R.D.; Schiestl, R.H. Large-scale high-efficiency yeast transformation using the LiAc/SS carrier DNA/PEG method. Nat. Protoc. 2007, 2, 38-41. [CrossRef] [PubMed]

32. Kersters-Hilderson, H.; Callens, M.; Opstal, O.V.; Vangrysperre, W.; Bruyne, C.K.D. Kinetic characterization of d-xylose isomerases by enzymatic assays using d-sorbitol dehydrogenase. Enzyme Microb. Technol. 1987, 9, 145-148. [CrossRef]

33. Livak, K.J.; Schmittgen, T.D. Analysis of relative gene expression data using real-time quantitative PCR and the 2- $\Delta \Delta C$ T method. Methods 2001, 25, 402-408. [CrossRef] [PubMed]

34. Wang, Z.; Ong, H.X.; Geng, A. Cellulase production and oil palm empty fruit bunch saccharification by a new isolate of Trichoderma koningii D-64. Proc. Biochem. 2012, 47, 1564-1571. [CrossRef]

35. Qi, X.; Zha, J.; Liu, G.G.; Zhang, W.; Li, B.Z.; Yuan, Y.J. Heterologous xylose isomerase pathway and evolutionary engineering improve xylose utilization in Saccharomyces cerevisiae. Front. Microbiol. 2015, 6, 1165. [CrossRef] [PubMed]

36. Vilela Lde, F.; de Araujo, V.P.; Paredes Rde, S.; Bon, E.P.; Torres, F.A.; Neves, B.C.; Eleutherio, E.C. Enhanced xylose fermentation and ethanol production by engineered Saccharomyces cerevisiae strain. AMB Express 2015, 5, 16. [CrossRef] [PubMed]

37. Madhavan, A.; Tamalampudi, S.; Srivastava, A.; Fukuda, H.; Bisaria, V.S.; Kondo, A. Alcoholic fermentation of xylose and mixed sugars using recombinant Saccharomyces cerevisiae engineered for xylose utilization. Appl. Microbiol. Biotechnol. 2009, 82, 1037-1047. [CrossRef] [PubMed]

38. Perez-Traves, L.; Lopes, C.A.; Barrio, E.; Querol, A. Evaluation of different genetic procedures for the generation of artificial hybrids in Saccharomyces genus for winemaking. Int. J. Food Microbiol. 2012, 156, 102-111. [CrossRef] [PubMed]

39. Ho, N.W.; Chen, Z.; Brainard, A.P. Genetically engineered Saccharomyces yeast capable of effective cofermentation of glucose and xylose. Appl. Environ. Microbiol. 1998, 64, 1852-1859. [PubMed]

40. Kuyper, M.; Harhangi, H.R.; Stave, A.K.; Winkler, A.A.; Jetten, M.S.; de Laat, W.T.; den Ridder, J.J.; Op den Camp, H.J.; van Dijken, J.P.; et al. High-level functional expression of a fungal xylose isomerase: The key to efficient ethanolic fermentation of xylose by Saccharomyces cerevisiae? FEMS Yeast Res. 2003, 4, 69-78. [CrossRef]

(C) 2018 by the authors. Licensee MDPI, Basel, Switzerland. This article is an open access article distributed under the terms and conditions of the Creative Commons Attribution (CC BY) license (http:// creativecommons.org/licenses/by/4.0/). 